\title{
IS THE HISTORY OF SCIENCE ESSENTIALLY WHIGGISH?
}

\author{
David Alvargonzález \\ University of Oviedo
}

\begin{abstract}
In this paper I will discuss whether the history of science is necessarily a Whig history. After briefly presenting the problem, I introduce the emic/etic distinction, which seems to me particularly relevant in this debate. I then advocate the existence of certain differences between the idea of progress as applied to social, economic or political history, and as applied to the history of techniques, sciences and technologies. I later claim that the tension between past and present plays an essential role in this history inevitably dotted with certain anachronism, thus affirming the essentially Whiggish nature of the history of science. To end, I discuss the relevance of the use of different scales when facing historical interpretation, and I claim that abridged scales are not necessarily more Whiggish than "microscopic" ones.
\end{abstract}

\section{KEY WORDS}

Whiggism, presentism, anachronism, ethnocentrism, scales in history, progress in science

\section{THE STIGMATIC LABEL OF 'WHIGGISM'}

In his influential 1931essay The Whig interpretation of history, Herbert Butterfield criticized what he called the "Whig history", the "study of the past for the sake of the present"; history, he stated, cannot be used to justify certain contents in the present. In particular, he denounced conceiving of history as a succession of goal-directed stages, such that past stages must be seen through the lens of their future goal. As his account goes, any investigation into the causes of historical change is hampered by anachronism, 
while any teleological, goal-directed narrative proves untenable. Butterfield, in the face of Whig historians, rather preferred an ideal whereby the past be studied "for the sake of the past"1, whereby the historian become more than a mere observer and one who actually "goes out to meet the past".

Chief in the reticle of Butterfield's book was the political history of the circumstances leading to the Protestant Reformation and the modern constitution of the English people. There, he contradistinguished Whig history, which understood the Reformation as an inevitable step towards progress, from the Catholic, Tory interpretation of the same event; for Butterfield, Luther was nothing of a progressive. Whiggism, for him, was inherently related to what he called "abridged" or "general history" itself rectified, so to speak, by a specialized, technical history of very concrete, detailed issues.

Around the same time as Butterfield, Alexandre Koyré published his well-known Études galiléennes in the field of the history of science. ${ }^{3}$ In these important essays, Galileo takes shape less as a modern experimentalist (as a hagiographic presentcentered history would have it) and more as a speculative Platonist seeking to refute Aristotelianism.

Since the mid-1970s, the labels "Whig" or "Whiggish" have been frequently used in history of science jargon to denigrate and repudiate certain histories of science which accept the idea of progress as an idea of significant value. This jargon, favoring a more skeptic, sociological approach, uses "Whiggism", "anachronism", "triumphalism", "presentism" and the like as labels to denote a chronological snobbery considering all things past as inherently inferior. "Studying the past with reference to the present", Whiggish history supposedly views the present as the inevitable product of the past. As such, past science is judged according to its contribution to theorems held as true in the present: the past is interpreted through current values, with a consequent dismissal of the problems and ideas of earlier scientists. ${ }^{4}$ Opposing both a history of science used to illustrate the historian's own view of science as well as any narrative of scientific progress, an inductive history establishes itself as the ideal of the professional historian of science. 
As Wilson and Ashplant have declared, "among professional historians of science the label of 'Whiggishness' is part of everyday discourse". ${ }^{5}$ No professional dare bear such a tag, for it brands a deep stigma: any historian seeking respect as "modern", "academic", "professional", "technical" and "intellectual" must label him/herself as "anti-Whiggish".

\section{THE EMIC/ETIC DISTINCTION AND ITS RELEVANCE TO THE DISCUSSION SURROUNDING THE WHIGGISH HISTORY OF SCIENCE}

Cultural anthropologists and linguists make use of the distinction, introduced by K. L. Pike, between the emic and etic standpoint. ${ }^{6}$ As defined by a well-known handbook of cultural anthropology, the emic point of view corresponds to the perspective of participants: "the test of the adequacy of emic descriptions and analyses is whether they correspond with a view of the world natives accept as real, meaningful, or appropriate." The etic standpoint is the observer's perspective, and the test of its adequacy "is simply its ability to generate scientific theories about the causes of social differences and similarities".

The dichotomy common in both linguistics (the native speaker vs. the outside learner) and in anthropology (the member of a culture vs. the observer) bears some resemblance to the situation faced by the present-day historian looking to reconstruct a bygone world which is largely alien to him/her. First introduced by Nick Jardine, this analogy between anthropology and history suggested that historians of science should learn from anthropology and seek out appropriate combinations of emic and etic perspectives. ${ }^{8}$ As such, the field of history may be organized according to two standpoints. The first - the emic standpoint - is characterized by the challenge to understand historical texts in their own context. Such a standpoint therefore seeks to expunge the historical record of all distortions, anachronisms and biased interpretations made by present-centered historians who make use and abuse of history to support their own theoretical assumptions. Conversely, the etic 
perspective suggests the relevance of the present in attempts to generate theories about historical processes. When adopting an etic point of view from the present, accusations of Whiggism and presentism made of historians would correspond to the charge of ethnocentrism often levied when anthropologists use their own civilization's categories to explain a foreign culture.

As clear from the preceding, the etic perspective seems to share features with Butterfield's so-called Whiggish history, thus establishing the emic perspective as the one worthy of respect. As Butterfield states, "The primary assumption of all attempts to understand the men of the past must be the belief that we can in some degree enter into minds that are unlike our own". ${ }^{9}$

The problem of the incommensurability between the intellectual milieu of two different historical moments does in some ways resemble the anthropological problem posed by translating between cultures. Accordingly, the anthropological claim for cultural particularism stands as the historical counterpart to the assumption that each historical moment has its own irreducible Zeitgeist. Butterfield sometimes borders on this historical Megarianism when he affirms that "the chief aim of the historian is the elucidation of the unlikeness between past and present". ${ }^{10}$ Such an anthropological particularism grounds itself on the fact that primitive cultures are autarchic and isolated, at least while they remain undiscovered. When moving into a historical discussion, though, the causal lines between the past and the present cannot be deleted. Hence, historians of science make use of the idea of incommensurability in order to isolate a given historical period. Taken to the extreme, this strategy leads to a temporary Megarianism whereby the world seems created ex novo each time (or, as Kuhn would say, each paradigm). Hints of Malebranche's occasionalism do not linger very far off from this philosophy.

Contrary to possible expectations, the emic and etic standpoints do not always coincide. A prominent example is provided by the study of scapulimancy or omoplatoscopy, as practiced by the Naskapi, a hunter-gatherer people living in northern and central Labrador (Canada). When a group of Naskapi goes hunting, they are accompanied by a shaman who performs the 
divination using scapulae. In a suitable place, he breaks the scapula of a caught animal; by studying the broken fragments of bone, the shaman deduces the place where the group will hunt that day. Undoubtedly the shaman emicly knows certain rules to administer his magic. Eticly, however, scapulimancy functions as a "random generator" which makes variation possible in the exploited hunting grounds, thus preventing overhunting in one given area. The same results would be obtained from the shaman throwing dice and then deciding where to hunt based on the values thrown, since the magic of the scapulae plays the (etic) role of alternating hunting locations, thus maintaining the ecological balance. In these cases, it could be said that the Naskapi do not adequately represent a situation which nevertheless surrounds them and their own behaviors.

Regarding the execution of works, the Scholastics made the precise distinction between the finis operis and the finis operantis. The finis operis - the end goal of the work - is inscribed in its structure, beyond even the will of its author; for instance, the end of the bridge will be to create a path for people to save the river. The finis operantis and, generally speaking, the subjective ends of the operations of those who plan the work may be very different: achieving prestige, getting rich or myriad others. Moreover, those involved in the execution of any given work may be unaware of its finis operis or may represent it in a confused and misleading way. It is well known that Christopher Columbus died believing he had reached China and Japan, long after Amerigo Vespucci's rectification. Sometimes, an individual believes he/she is pursuing an objective goal, but this is purely chimerical or mythological: building a perpetual motion machine is a meaningless goal because its finis operis is impossible. However, this goal may serve for others as a challenge or inspiration to build real machines that do indeed have an objective interest, one which was not adequately represented by the inventor. Similarly, an atheist may view those who place their life's goal in achieving bodily resurrection as following a spurious aim, an aim which could, nevertheless, provide worthwhile cues on how to organize their behavior.

The examples presented above serve to illustrate the limitations of any a priori assumptions made to the effect that 
subjective goals or the emic perspective exhaustively cover possible understandings of a given work. Naturally, there are some occasions when emics and etics match. This coincidence, however, must not be taken for granted, for there is no reason to think beforehand that anthropological or historical analysis must limit itself to a person's emic account and his/her subjective ends. As alien as it may seem, the etic perspective is oftentimes more true, as evidenced by Columbus. Other times, the emic perspective is, if not false, either incomplete or insufficient since the agent is unaware of certain structures which shape him/her from the outside and thus provide objective meaning to his/her work, as in Naskapi scapulimancy.

As it is, emics has secured considerable prestige in both anthropology and the history of science. Writing in no uncertain terms about the identity and the invention of science, Andrew Cunningham claims a radically emic standpoint in which science is a human activity, and nothing but a human activity, such that reconstructing its history ends by unveiling the subjective goals of its agents. ${ }^{11}$ From his point of view, it is erroneous to say that Newton was making science because his (emic) goal was knowledge of God. My view though, as buttressed by both Columbus and Naskapi shamans, values the etic standpoint as equally relevant historically. For me, Newton was dealing with planets, projectiles, free-falling objects and the like, and he did this in such a way that his work could be qualified as a strictly scientific.

If we deal with the history of science emicly, it would be anachronistic to speak of non-Euclidean geometries when discussing Euclides' Elements, anachronistic to speak of Watson and Crick when discussing Mendel's laws, and anachronistic to speak of Newtons' mechanics when discussing Kepler. Judging Kepler from Newton, Mendel from Watson, or Euclid from Riemann would be the most direct way to betray their original thought, the spirit of their time, and their own vision of the problems. The emic perspective disallows contemporary interpretation of ancient texts and presents the original texts in an attempt to understand them by making sole use of contemporaneous categories. The aim is therefore to frame these texts within the society and culture of the time in order to determine the place they occupied at that moment in 
history. Hence, only improperly could Apollonius's conics be considered in light of modern equations, or the Greek numerals in light of the Arabic system. Rather, it would be necessary to rebuild the relationships that conical curves or Greek numerals had with the social, economic, ideological and political milieu of their time. Emics, however, run one important risk: by dint of denying the relevance of current categories to interpret the past, the work of the historian becomes one of contextualization and attempts to deduce the entire contents of the sciences from social, political or economic conditions or from the techniques of a given age.

Let me be clear: my goal is not to deny the importance and necessity of conducting detailed philological studies on the materials contained in the history of science in order to prevent misrepresentation or distortions of the original texts. On many occasions, etic categories are undoubtedly a source of distortion, as occurs when the application of an etic anachronism directly proves to be a nuisance. I agree with Jardine that the notions of Foucault's "episteme" and Bourdieu's "habitus" are examples of such sterile etic categories. ${ }^{12}$ However, distance from the present, as proposed by emics, seems a difficult thing to accomplish, for any informed analyst cannot honestly ignore the zero or decimal notation when tackling Greek numerals. Conic equations come part and parcel with any modern understanding of Apollonius, just as general relativity inevitably comes part and parcel with understanding the coincidence of gravitational and inertial mass in Newtonian mechanics. Ptolemaic cosmology can only be understood historically in reference to the Copernican, Keplerian and Newtonian systems. Any affirmation that the truths found in the history of science can be set aside is merely pretension, a feigned attempt to ignore their relevance in our lives today, even if this relevance only implies our correcting of the miscalculations or shortcomings of yesterday. As A. Rupert Hall once stated, "the most obvious of all historical questions is: How did we arrive at the condition we are now in?" ${ }^{13}$ For instance, phrenology's place as a pseudoscience in relation to other contents in the history of neurology is due to our later knowledge. Similarly, the problem of understanding the meaning of Babylonian astrology historically does not stand independent of its truth value - 
a value which cannot be extrapolated from the socio-historical context of the time. Removing this truth value merely leads to the simple historical understanding of Babylonian astrology as "a manifestation of the Babylonian culture" or of the Ptolemaic system as "a manifestation of a certain Greco-Roman culture", and so on into oblivion.

Nick Jardine has convincingly advocated the need for the etic perspective in the study of certain important episodes in the history of science, such as Gingerich and Voelkel's use of modern stellar computations when studying Martian parallax as observed by Tycho Brahe in the 1580s. He has also argued for the need for etic categories in understanding the horrors that people faced in the $14^{\text {th }}$ century during the Black Death. In other cases, knowledge of modern medicine has allowed us access to realities unknown to the actors, as evidenced by the autopsy performed on the mummified Ramses II, which enabled us to identify tuberculosis as the cause of his death. ${ }^{14}$ Jardine also believes that critical respect for past agents requires studying the etic ways in which their "cultural strategies and their perceptions are conditioned by social and institutional situations". Such an affirmation rings of Norbert Elias, who had tried to bring this view into some of his classical studies. ${ }^{15}$ Again, it is important to note that these comments are not directed against the necessity of emics in the history of science, but rather they try to identify some of its essential, constituent problems. One of these problems is that emicist historians, in the course of their work, must apply some standard of demarcation to distinguish true science from pseudoscience - thermodynamics from necromancy, for instance and so exercise a certain idea of science consolidated from the present, a certain updated, and therefore etic, philosophy of science. As Nick Jardine recognizes, "[...] a total ban on appeal to knowledge not possessed by the agents studied is a recipe for historiographical paralysis". ${ }^{16}$

The relationship between etics and emics in the history of science has proven inevitably problematic. Emicist historians pounce on any inaccuracy or anachronism made by present-minded historians, while etic accounts either fail to use the findings gathered emicly or forward their positions while awaiting the potential 
sociological reductionism often held by a historical contextualist Meganiarism itself linked to emic accounts. Since we are not gods observing the world from the heavens, "present-centredness is inherent in the process of historical research, and hence [...] historical inference is inherently problematic". ${ }^{17}$

\section{THE IDEA OF PROGRESS AND ITS PLACE IN THE HISTORY OF TECHNIQUES, SCIENCES AND TECHNOLOGIES}

The criticism forwarded by Herbert Butterfield against the Whig interpretation of history directly confronts the assumption of mankind's moral progress. Butterfield considers that "the dispensing of moral judgments upon people or upon actions in retrospect [is] the most useless and unproductive of all forms of reflection". ${ }^{18}$ Elsewhere, however, he himself recognized the existence of scientific and technological progress, as evidenced in Chapter 10 of The origins of modern science, 1300-1800, "The place of the scientific revolution in the history of western civilization". ${ }^{19}$ In the following, I will assume that transferring the Whig label from political, economic and moral history onto the history of sciences and technologies necessitates a discussion of the idea of progress.

Suppose that speaking of $K$ progress in a given succession requires defining a dynamic finite substrate in relation to its medium. (As a prerequisite for a discussion on progress, the sequence must have more than two steps since two steps would be more appropriately referred to as a "platform" or "bench". Progress cannot be accurately detected if we are only considering the present/past or modern/ancient dichotomy: two steps are not enough in order to define a succession as progressive.) Assume as well that progress implies a recurrent amelioration, given a certain $K$ parameter. Based on these principles, therefore, it is very important to realize that the relationship of progress - just as the geometric relationship of parallelism - is a connected relationship that can lead to one progress-line transecting and thus conflicting with others, for two parallel lines are not necessarily parallel with all others. For 
instance, progress in the speed of a succession of cars may conflict with progress in security ${ }^{20}$.

Regarding techniques, it seems impossible to deny the existence of progress. The so-called Mode IV industries typical of the Upper Paleolithic represent a marked increase in tool effectiveness when compared to the first Oldowan and Acheulean industries. The same is true when it comes to technological progress: it is absurd, judging from certain variables such as safety, comfort and speed, to deny the progress of aviation technology; it is impossible, taking therapeutic success as the standard, to disprove the progress of medical technologies. Even the most skeptical, postmodern cultural relativists would not doubt this issue when suffering as patients, when the primacy of their practical reason (the primacy of the rationality of their own operations) imposed itself upon their speculative skepticism.

Generally speaking, one could argue that technologies are more efficient than predecessor techniques, since the former require using scientific theorems and controlling certain meaningful causal relations. Comparing ancient medical techniques to current medical technologies brings this to the fore. Geddes and Mumford's three stages - eotechnic, paleotechnic and neotechnic - could be interpreted as if they were progressive stages, taking efficiency in energy management as a substrate of reference. ${ }^{21}$ As such, history in the field of techniques and technologies will always have an essentially Whig component because the achievements of the past are inevitably included in a progressive succession which continues up to the present. As mentioned, technical and technological progress always makes reference to a certain finite and limited substrate (speed, therapeutic success, instrumental efficiency and the like); it does not refer to the "world in general" or to the "general welfare of mankind". Progress, as I take it, requires defining a particular substrate in relation to its environment.

Numerous current philosophers and historians of science hold the view that one cannot speak about progress in science. The idea of science that has emerged from Edinburgh-style sociology implies a widespread skepticism of scientific objectivity and of the existence of progress in a given science. For these philosophers and 
historians, scientific theorems are nothing but a social construct. As far back as the 1970s, Brush was already noting that the objectivity of science was under attack and that scientific truth was becoming a matter of persuasion and conversion. ${ }^{22}$ Shortly thereafter, Arnold Thackray too stated that the idea of progress is irrelevant to the history of science. ${ }^{23}$ Cunningham, in this line, provided another significant example, positing that science is nothing special because it is a human activity "and nothing but a human activity". ${ }^{24}$ Such tenets have radically questioned both the specialness and progress of science. ${ }^{25}$

Nonetheless, the idea that scientific theorems are contingent on culture cannot explain how is it possible to discover certain phenomena which could not have been foreseen at the moment of that theory's promulgation, but which confirm it nonetheless. For instance, Einstein's predictions on relativity were later upheld using technologies which were unavailable in $1915 .{ }^{26}$ Furthermore, as Jim Secord sharply affirms, "the rejected narratives of triumphal progress still tend to determine the choice of research topics (figures, disciplines or works)", and they still tend to do so even amongst the most anti-Whiggish sociologists. ${ }^{27}$

To be fair, the issue of whether a new theorem can be considered progressive in a current science may be disputed in relation to a science currently undergoing its own constitution. In the history of science, though, agreement in recognizing some scientific progress in a sequence of sufficiently large and distant events can only be unanimous. Tycho's observations and Kepler's use of them have undoubtedly come to represent important progress in accuracy vis-à-vis Ptolemy and Hipparchus. The study of irrationals surely corrected the impossible quadrature of the square. Kepler's orbits and three laws obviously represent a breakthrough in simplicity compared to Ptolemy or Copernicus. Not even the most skeptical sociologist would today doubt that Schiaparelli's observations of Martian canals have been corrected by later observations. The progress represented by Newtonian unification seems self-evident. Butterfield himself recognized the progressive nature of scientific chemistry in relation to ancient alchemy. ${ }^{28}$ 
Viewed from the tenets of a materialist philosophy, the essential function of science is not to represent reality, to build technology or to dominate the world. While science indeed performs all these functions, its main function may not be reduced to any of them. Reality itself should be regarded as in fieri, dependent in many places on scientific truths and theorems. In this, materialism posits a sort of "hyper-reality", an "extended reality" accounting not only for what directly strikes our senses (appearances, phenomena) but also for everything which operates, exists and determines other things though not directly perceived, such as electromagnetic waves, atomic structures, geometric relations or evolutionary processes. The most characteristic function of science, then, is to constitute certain parts of this hyper-reality. Science builds hyperreality as it progressively expands. As such, the history of scientific progress is nothing but the history of this progressive expansion. ${ }^{29}$ From this point of view, the analysis of scientific progress cannot be reduced to the study of relations between successive scientific theories, since it strongly denies that sciences could be considered only as theories. ${ }^{30}$ The existence of a multitude of simultaneous discoveries (Hooke and Newton, Leibniz and Newton, Darwin and Wallace, etc.) serves as indication that scientific theorems are bound to a certain structure of reality independent from the agents.

However, defending the existence of a certain progress in the history of science need not assume such a strong realism as the above-mentioned materialist hyper-realism. Scientific progress has been justified on a wide range of criteria such as accuracy, logical consistence, scope, simplicity, fruitfulness and predictive or explanatory power. In the $19^{\text {th }}$ century, Whewell employed the ideas of unification and consilience to understand scientific progress. ${ }^{31}$ Critiquing a teleological metaphysics of progress, structural realists such as Stegmüller, Balzer and Scheibe have been able to account for scientific progress as a process of empirical reduction of theories. ${ }^{32}$ Pragmatists and instrumentalists such as Toulmin understand scientific progress as the increasing empirical success of scientific theories. ${ }^{33}$ Popper and Niiniluoto, for their part, are also examples of proponents of "progress-friendly" positions as seen in their ideas of truthlikeness and verisimilitude ${ }^{34}$ even Kuhn, from his 
influential discontinuist standpoint and based on his idea of science as a problem-solving activity, has argued for the existence scientific progress (at least when considered from a backward-looking perspective).${ }^{35}$ Further examples abound, for the idea that science is progressive seems compatible with a wide spectrum of conceptions of science.

As Alfred Rupert Hall once stated, the historian of science "cannot deny that science has progresses, even if he should for other reasons regret the fact and its consequences" ${ }^{36}$ For the purposes of this paper, both discussing the consequences of this fact and speculating about "what would have been good or better according to the perspective of mankind" is irrelevant; let it be enough to recognize that such scientific progress exists, for better and for worse. In any case, though, we must distance ourselves from the pretentious Faustian ideal of the domain of Nature, so common in $19^{\text {th }}$ century positivists and some $20^{\text {th }}$ century neopositivists: it is clear that we cannot expect to have dominion over the galaxy, over geological processes, or over the solar dynamics influencing Earth's climate, among others.

Recognizing progress in science does not require adhering to an exclusively cumulative conception of the history of sciences, as George Sarton did. ${ }^{37}$ Progress in science is compatible with the recognition and study of failed theories, closed paths and dead ends, such as phlogiston theory or Lamarckian evolution. Such culde-sacs must be explored in order to understand the role played by trial and error in the history of theorems. Furthermore, it is worth noting that negative knowledge, such as the absence of spontaneous generation, is also a certain kind of knowledge.

Ernst Mayr, one of most reputed evolutionary biologists, once drew an analogy between the history of science and Darwinian evolution in order to understand scientific progress:

Scientific progress $[\ldots]$ is obeying the principles of Darwinian variational evolution which has no teleological components. For a scientist who adheres to Darwinism there is nothing wrong or unscientific in following the evolution, and usually progress, of a scientific idea. 
Those who object to this procedure do so because they do not understand the interplay between variations and selection, which is as active in the history of ideas as it is in organic nature. This has nothing to do with teleology or a naïve belief in an intrinsic drive towards progress. Inevitably it includes a treatment of false starts and of competing theories. Yet it does not necessitate exploring every long forgotten blind alley in the development of science. However, it must make use of our modern understanding of particular scientific concepts or problems in order to be able to explain the reasons for the difficulties of former periods. ${ }^{38}$

When understood from the synthetic theory of evolution, this analogy between the biological evolution of species and the progress of science has interesting applications in many contexts, but certain fundamental differences between these two processes should nevertheless be noted. In biological evolution, genetic variation is random, and natural selection acts on this random variation. In the history of science, though, theorems do not proliferate randomly, for subjects performing scientific research display, whether appropriately or not, purposive behavior in the face of certain objectives. Moreover, successful theorems are not inherited in the same way as genetic variations, but are spread immediately through learning. At most we could speak of some sort of "inheritance of acquired characteristics". Accordingly, no "progress in biological species" takes place, but progress does indeed occur in the sciences. Additionally, Rescher's influential work on the problem of applying the law of diminishing returns to scientific research is a hotly debated issue lacking any clear counterpart in biological evolution. ${ }^{39}$

Finally, advocating progress should take more nuanced tones when it comes to the social sciences. This clarification, though, should not be considered an ad hoc exception to my stance, but rather as a consequence of these sciences' specific epistemological status. Here, I have assumed that the social sciences do not achieve strict scientificity, as occurs in the natural and formal 
sciences. For this reason, applying the idea of progress to these sciences proves problematic and, consequently, the discussion of Whiggism in their history poses special difficulties. ${ }^{40}$

\section{THE TENSION BETWEEN PAST AND PRESENT AS ESSENTIAL TO THE HISTORY OF TECHNIQUES, SCIENCES AND TECHNOLOGIES}

According to Hull, certain forms of presentism are undesirable and may be discarded, while others are legitimate and still others prove to be necessary evils. ${ }^{41}$ Condemning earlier science for ignoring what we know now today is a form of eliminable presentism. However, one must necessarily use one's own language in writing about the past, for a historian's task is not only to reconstruct but also to make use of current language and science to communicate their results to their contemporaries. ${ }^{42}$ Similarly, it is not always possible to set aside one's knowledge about science since it is difficult to imagine how a historian could avoid any knowledge about the science of his/her own time.

Historians, it must be stressed, must always avoid bias, chauvinism, finalism and all forms of historiographical malpractice. Such a negligent employment of anachronism, as has been noted elsewhere, occurs infrequently in professional historians of science $^{43}$. But to avoid these errors, we must "be careful not to throw out the baby with the bath water".

As Wilson and Ashplant have stated, we have to be aware that "the questions which structure the historian's enquiry, and which indeed have defined these particular relics of the past as a source of potential evidence for that enquiry, derive from the present" ${ }^{\text {" }}$. Therefore, "present-centredness is inherent in the process of historical research, and hence [...] historical inference is inherently problematical" ${ }^{45}$ For these reasons, this paper heavily echoes Alfred Rupert Hall in his declaration:

I seems to me that the 'Whig interpretation' in

Butterfield's terms is necessarily inherent in many proper 
kinds of historical writing, that indeed 'Whiggism' is a necessary part of linear history, I would not be taken as meaning that the faults and errors of Whig historians are either beyond correction or not worth correction [...] the reader is entitled to expect that the linear history be written as strictly, its speculations be as well founded, and the search for causes and explanations be as prudent, as the limitations of human intellect and endeavour will allow. ${ }^{46}$

This does not require discarding the forward-looking way in the history of sciences, for such a viewpoint is always necessary to understand why certain subjects acted the way they did, even when later discoveries proved them wrong. Nevertheless, the backwardlooking way too seems inescapable, since early theorems and artifacts still remain in our modern science and technology, oftentimes just as they were initially presented and sometimes as contents to be rectified. It is therefore necessary to maintain both the backward and the forward perspective of the history of techniques, sciences and technologies. In that, a certain conceptual anachronism is indispensable.

In a sort of ad hominen argument, Edward Harrison says that "many historians adopt a superior attitude to historical work by scientists, and from fear of being unhistorical commit what they suppose is the lesser crime of being unscientific". He goes on to state that they are "unscientific in the sense that they received their training in the humanities or social sciences". They make a virtue of necessity, and justify the ignorance of modern science, grounding themselves on the tenet that this science did not exist yesterday. Trained exclusively in the humanities, these professional historians attempt to defend their new territory by condemning the historianscientists as Whiggish. ${ }^{47}$

Regardless of the validity of this interpretation of the war between historian-humanists and historian-scientists, Harrison points out two important issues: first, that "reconstructing the past requires vigilant commentary on differences between past and present sciences and languages"; and second, that the "awareness 
of temporal depth in science forms an integral part of scientific research". Scientists cannot be excluded from the history of science because this history is necessary to judge the impact had by circumstances in the former periods on the later development of sciences and technologies. ${ }^{48}$ Ernst Mayr also insists on this latter idea, when he says "the reason for this interest [the scientist's interest in history] is that it is impossible to understand many of the current controversies and prevailing concepts without studying their history" ${ }^{\text {"49 }}$. Mayr concludes by saying that "it is by no means wrong to look at the past on the basis of our understanding of the present". ${ }^{50}$

Briefly restated and based on an assumption of the essential nature of progress, the history of techniques, sciences and technologies, implies a certain, asymmetric tension between the present and the past: asymmetric, for the past may be understood from the present, but the present (within a hierarchical scale of superiority) may not always be understood from the past.

\section{THE RELEVANCE OF THE DIFFERENT SCALES}

In the wake caused by Herbert Butterfield's famous book, broadscale history has been discredited in favor of a technical, specialized and professionalized history. The history of large-scale processes is often labeled as an ideological history with a profound lack of scientific accuracy; a bird's eye view is often considered the history of amateurs. Butterfield clearly associates abridged history with the assailed Whig history. In his conception of historical science, the problems of historical interpretation can only be solved with more accurate study, greater detail and more concreteness, that is, by being as detailed as possible. To quote:

The volume and complexity of historical research are at the same time the result and the demonstration of the fact that the more we examine the way in which things happen, the more we are driven from the simple to the complex. It is only by undertaking an actual piece of 
research and looking at some point in history through the microscope that we can really visualize the complicated movements that lie behind any historical change. It is only by this method that we can discover the tricks that time plays with the purposes of men, as it turns those purposes to ends not realized; or learn the complex process by which the world comes through a transition that seems a natural and easy step in progress to us when we look back upon it. It is only by this method that we can come to see the curious mediations that circumstances must provide before men can grow out of a complex or open their minds to a new thing. ${ }^{51}$

In the last resort the historian's explanation of what has happened is not a piece of general reasoning at all. $\mathrm{He}$ explains the French Revolution by discovering exactly what it was that occurred; and if at any point we need further elucidation, all that he can do is to take us into greater detail, and make us see in still more definite concreteness what really did take place. ${ }^{52}$

The analogy between the different historical and spatial scales can aid in understanding some of the problems posed by Butterfield's interpretation. Looking at maps, it is clear that certain important, geographical morphologies, such as a large peninsula, a long river, the continuity of an extensive mountain chain and the like, pass unnoticed on a micro scale. These features cannot be drawn out by using an even more microscopic scale. Looking at history, the consequences of certain events require reference to processes taking place much later: the consequences stemming from the discovery of America, the Principia or the French Revolution completely fade when we go down into the details of the life of Columbus, Newton or Robespierre. As such, deep subterranean movements of the utmost historical significance exist, even if they demur unnoticeable from the contingent, surface micro-movements. Certain demographic variables serve as examples of these deep dynamic secular trends. In any map, a smaller and smaller scale 
leads to a fictitious map which coordinates every point on the map with every point of the land, as does "Royce's map" or Lewis Carroll's map "of one mile to the mile". In the field of history, the correlate ideal of approaching as close as possible to the documents would render any interpretation impossible. Butterfield himself admitted that if "history could be told in all its complexity and detail it would provide us with something as chaotic and baffling as life itself". ${ }^{53}$ At the same time, Butterfield calls for an absolute contingentialism when he says that "for the historical technician the only absolute is change". ${ }^{4}$

Realizing the difficulties therein, Alfred Ruppert Hall criticizes what he considers Butterfield's specious inductivism:

I find great difficulty in this analogy between the historical process and a microscope with a zone-lens system, not least in the fact equally of optics and history that increase of magnification entails reduction of the field of view. ${ }^{55}$

Butterfield's book advocates an anti-Whig conception of history which rejects selectiveness. He is against simplifying the study of history "providing an excuse for leaving things out".$^{56}$ Being selective, though, does not necessary mean being biased or finalistic. As Alfred Ruppert Hall says, "Selection must be made, and since it would be absurd for selection to be random, it must be made in accord with certain principles, that is a pattern" ${ }^{57}$ Hence, the meaningful issue for the historian is not the absence of selection but "whether the framework he/she is using is appropriate to the past he/she is studying". ${ }^{8}$

As mentioned above, Butterfield discusses the place of scientific revolution in the history of Western civilization in Chapter 10 of The origins of modern science $1300-1800 .^{59}$ There, he discusses the special significance of certain historical places and periods. He says:

But we cannot hold our history in our minds without any landmarks, or as an ocean without fixed points [...]. 
Similarly, though everything comes by antecedents and mediations and these may always be traced farther and farther back without the mind ever coming to rest - still, we can speak of certain epochs of crucial transition, when the subterranean movements come above ground, and new things are palpably born, and the very face of the earth can be seen to be changing. ${ }^{60}$

After comparing the scientific revolution to other relevant historical events (the Renaissance, the discovery of America, the Reformation, etc.), Butterfield concludes that "since the rise of Christianity, there is no landmark in history that is worthy to be compared with [the scientific revolution]". ${ }^{61}$ Butterfield, however, never wrote this specialized, technical history of science which he advocated in his 1931 book. The origins is rather a good sample of broad-scale history in which judgments about progress are not lacking. The undeniable interest and fertility of this classic book are evidence that no particular scale, be it broad or microscopic, may be discarded.

\section{AKNOWLEDGEMENTS}

The anonymous referee of History of science made valuable suggestions to improve the first version of the paper. Brendan Burke made a careful revision of the manuscript. Finally, I want to honor philosophers Gustavo Bueno and Vidal Peña, whose philosophy provides the main source of inspiration for this work.

\section{REFERENCES}

${ }^{1}$ Herbert Butterfield, The whig interpretation of history (London, 1931), 16.

${ }^{2}$ Butterfield, op.cit (ref.1), 92.

${ }_{3}^{3}$ Alexander Koyré, Études galiléennes (Paris, 1931-39).
Con formato: Inglés (Estados Unidos)

Con formato: Inglés (Estados Unidos) Con formato: Inglés (Estados Unidos) Con formato: Inglés (Estados Unidos) Con formato: Inglés (Estados Unidos) Con formato: Inglés (Estados Unidos) Con formato: Inglés (Estados Unidos) 
${ }^{4}$ Stephen G. Brush, "Should the history of science be rated X? Science, 22 (1974), 183, p.1169.

${ }^{5}$ Adrian Wilson and T. G. Ashplant, "Whig history and presentcentered history", The historical journal (1988), 31, p.3.

${ }^{6}$ Kenneth Lee Pike, Language in relation to a unified theory of the structure of human behaviour (The Hague, 1967).

${ }_{7}^{7}$ Marin Harris, Culture, people, nature. An introduction to general anthropology (New York, 1985), p.124.

${ }^{8}$ Nick Jardine, "Etics and emics (not to mention anemics and emetics) in the history of the sciences", History of science, vol. 42, (2004), 261-278.

${ }_{9}^{9}$ Butterfield, op.cit. (ref.1), p. 9.

${ }^{10}$ Butterfield, op.cit. (ref.1), p. 10.

${ }^{11}$ Andrew Cunningham, "Getting the game right: some plain words on the identity and invention of science", Studies in history and philosophy of science, 19 (1988), 365-89.

${ }^{12}$ Jardine, op.cit. (ref. 8), p. 272.

${ }^{13}$ A. Rupert Hall, "On Whiggism", History of science, xxi (1983), p.

54.

${ }^{14}$ Nick Jardine, op.cit. (ref.8), p. 270.

${ }^{15}$ Jardine, op.cit. (ref.8), p. 273-4. See also N. Elias, The civilising process [1939], transl. By E. Jephcott (2 vols. Oxford, 1978, 1982), and The court society [1969], transl. By E Jephcott (Oxford, 1983).

${ }^{16}$ Nick Jardine, "Whigs and stories: Herbert Butterfield and the historiography of science", History of science, xLi (2003), p. 134. ${ }^{17}$ Wilson and Ashplant, op.cit. (ref. 5), p. 16.

${ }^{18}$ Butterfield, op.cit. (ref.1), p. 108.

${ }^{19}$ Herbert Butterfield, The origins of modern science, $1300-1800$

(London, 1949), 175-190.

${ }^{20}$ Gustavo Bueno, "Diez lecciones acerca de la idea de progreso"

("Ten lessons on the idea of progress", University of Oviedo, 1994, unpublished).

${ }^{21}$ Patrick Geddes, Cities in evolution (London, 1915).

Lewis Mumford, Technics and cvilization (New York, 1934).

${ }^{22}$ Brush, op.cit. (ref.4), p. 1167.
Con formato: Inglés (Estados Unidos)

Con formato: Inglés (Estados Unidos)

Con formato: Inglés (Estados Unidos)

Con formato: Inglés (Estados Unidos)

Con formato: Inglés (Estados Unidos)

Con formato: Inglés (Estados Unidos)

Con formato: Inglés (Estados Unidos)

Con formato: Inglés (Estados Unidos)

Con formato: Inglés (Estados Unidos)

Con formato: Inglés (Estados Unidos)

Con formato: Inglés (Estados Unidos)

Con formato: Inglés (Estados Unidos)

Con formato: Inglés (Estados Unidos)

Con formato: Inglés (Estados Unidos)

Con formato: Inglés (Estados Unidos)

Con formato: Inglés (Estados Unidos)

Con formato: Inglés (Estados Unidos)

Con formato: Inglés (Estados Unidos)

Con formato: Inglés (Estados Unidos)

Con formato: Inglés (Estados Unidos)

Con formato: Inglés (Estados Unidos)

Con formato: Inglés (Estados Unidos)

Con formato: Inglés (Estados Unidos)

Con formato: Inglés (Estados Unidos)

Con formato: Inglés (Estados Unidos)

Con formato: Inglés (Estados Unidos) 
${ }^{23}$ Arnold Thackray, "The pre-history of an academic discipline: The study of the history of science in the United States, 1891-1941", Minerva, xviii, p. 458.

${ }^{24}$ Cunningham, op.cit. (ref.11), p. 370.

${ }^{25}$ Cunningham, op.cit. (ref.11) 367-9, 387.

${ }^{26}$ Kurt Gottfried and Kenneth G. Wilson, "Science as a cultural construct", Nature, vol. 386 (1997), p. 547.

${ }^{27} \mathrm{Jim}$ Secord, "Introduction", The British journal for the history of science, xxvi (1993), 387-9.

${ }^{28}$ Butterfield, op.cit. (ref.19), 191-209.

${ }^{29}$ Gustavo Bueno, Teoría del cierre categorial (Oviedo, 1992).

Gustavo Bueno, La función actual de la ciencia (Las Palmas, 1995).

${ }^{30}$ Cfr. Craig Dilworth, Scientific progress: A study concerning the nature of the relation between successive scientific theories

(Dordrecht, 1981); Ilkka Niiniluoto, Is science progressive?

(Dordrecht, 1984), and Ilkka Niiniluoto "Scientific progress", The

Stanford encyclopedia of philosophy (2011).

${ }^{31}$ William Whewell, Novum organon renovatum, (London, 1858).

${ }^{32}$ Wolfgang Stegmüller, The structure and dynamics of theories, (Newyork-Heidelber-Berlin, 1976). Erhard Scheibe, "Conditions of progress and comparability of theories", in R.S.Cohen et al (eds.), Essays on memory of Imre Lakatos, (D. Reidel, 1976), 547-68.

Wolfgang Balzer, "On approximate reduction", in Jonkisz and Koj, On comparing and evaluating scientific theories,(Amsterdam, 2000), 153-70.

${ }^{33}$ Stephen Toulmin, Human understanding, (Oxford, 1972).

${ }^{34}$ Karl Popper, Conjectures and refutations: The growth of scientific knowledge, (London, 1963). Karl Popper, Objective knowledge: an evolutionary approach, (Oxford, 1972). Ilkka Niiniluoto, Critical scientific realism, (Oxford, 1999).

${ }^{35}$ Thomas Kuhn, The essential tension, (Chicago, 1977).

${ }^{36}$ Rupert Hall, op.cit. (ref.13), p. 58.

${ }^{37}$ George Sarton, Introduction to the history of science, Baltimore, 1927-48).

${ }^{38}$ Ernst Mayr, "When is historiography Whiggish?", Journal of the history of ideas, vol. Li (1990), p. 305.
Con formato: Inglés (Estados Unidos)

Con formato: Inglés (Estados Unidos)

Con formato: Inglés (Estados Unidos)

Con formato: Inglés (Estados Unidos)

Con formato: Inglés (Estados Unidos)

Con formato: Inglés (Estados Unidos)

Con formato: Inglés (Estados Unidos)

Con formato: Inglés (Estados Unidos)

Con formato: Inglés (Estados Unidos)

Con formato: Inglés (Estados Unidos)

Con formato: Inglés (Estados Unidos)

Con formato: Inglés (Estados Unidos)

Con formato: Inglés (Estados Unidos)

Con formato: Inglés (Estados Unidos)

Con formato: Inglés (Estados Unidos)

Con formato: Inglés (Estados Unidos)

Con formato: Inglés (Estados Unidos)

Con formato: Inglés (Estados Unidos)

Con formato: Inglés (Estados Unidos)

Con formato: Inglés (Estados Unidos)

Con formato: Inglés (Estados Unidos)

Con formato: Inglés (Estados Unidos) 
${ }^{39}$ Nicholas Rescher, Scientific progress, (Pittsburgh, 1978). John Horgan, The end of science: facing the limits of science in the twilight of the scientific age, (New York, 1996).

Roland Wagner-Döbler, "Rescher's principle of decreasing marginal returns of scientific research", Scientometrics, vol. 50/3 (2001), 419-

36.

${ }^{40}$ Franz Samelson, "Whig and anti-Whig histories. And other curiosities of social psychology", Journal of the history of the behavioral sciences. Special Issue: Re-engaging the history of social psychology, vol. 36/4(2000), 499-506.

Raff and Temin Lamoreaux, "Against Whig history", Enterprise and society, vol. 5/3 (2004), 376-87.

${ }^{41}$ David L. Hull, "In defense of presentism", History and theory, vol.18/1 (1979), p. 3.

${ }^{42}$ Hull, op.cit. (ref.41), p. 4.

${ }^{43}$ Jardine, op.cit. (ref.8), p.128.

${ }^{44}$ Wilson and Ashplant, op.cit. (ref. 5), 13. See also Nick Jardine,

"The uses and abuses of anachronism in the history of science",

History of science, xxxviii (2000), 251-70.

${ }^{45}$ Wilson and Ashplant, op.cit. (ref. 5), p. 16.

${ }^{46}$ Rupert Hall, op.cit. (ref.13), p. 54.

${ }^{47}$ Edward Harrison, "Whigs, prigs and historians of science", Nature, vol. 329 (1987), p. 214.

${ }^{48}$ Harrison, op.cit. (ref.47), p. 214.

${ }^{49}$ Mayr, op.cit. (ref.38), p. 304.

${ }^{50}$ Mayr, op.cit. (ref.38), p. 308.

${ }^{51}$ Butterfield, op.cit. (ref.1), p. 20-21.

${ }^{52}$ Butterfield, op.cit. (ref.1), p. 72.

${ }^{53}$ Butterfield, op.cit. (ref.1), p. 97.

${ }^{54}$ Butterfield, op.cit. (ref.1), p. 58.

${ }^{55}$ Rupert Hall, op.cit. (ref.13), p. 51.

${ }^{56}$ Butterfield, op.cit. (ref.1), p. 24.

${ }^{57}$ Rupert Hall, op.cit. (ref.13), p. 52.

${ }^{58}$ Wilson and Ashplant, op.cit. (ref. 4), p. 11.

${ }^{59}$ Butterfield, op.cit. (ref.19), 175-190.

${ }^{60}$ Butterfield, op.cit. (ref.19), p.180.
Con formato: Inglés (Estados Unidos)

Con formato: Inglés (Estados Unidos)

Con formato: Inglés (Estados Unidos)

Con formato: Inglés (Estados Unidos)

Con formato: Inglés (Estados Unidos)

Con formato: Inglés (Estados Unidos)

Con formato: Inglés (Estados Unidos)

Con formato: Inglés (Estados Unidos)

Con formato: Inglés (Estados Unidos)

Con formato: Inglés (Estados Unidos)

Con formato: Inglés (Estados Unidos)

Con formato: Inglés (Estados Unidos)

Con formato: Inglés (Estados Unidos)

Con formato: Inglés (Estados Unidos)

Con formato: Inglés (Estados Unidos)

Con formato: Inglés (Estados Unidos)

Con formato: Inglés (Estados Unidos)

Con formato: Inglés (Estados Unidos)

Con formato: Inglés (Estados Unidos)

Con formato: Inglés (Estados Unidos)

Con formato: Inglés (Estados Unidos)

Con formato: Inglés (Estados Unidos)

Con formato: Inglés (Estados Unidos)

Con formato: Inglés (Estados Unidos)

Con formato: Inglés (Estados Unidos)

Con formato: Inglés (Estados Unidos)

Con formato: Inglés (Estados Unidos)

Con formato: Inglés (Estados Unidos)

Con formato: Inglés (Estados Unidos)

Con formato: Inglés (Estados Unidos)

Con formato: Inglés (Estados Unidos)

Con formato: Inglés (Estados Unidos)

Con formato: Inglés (Estados Unidos)

Con formato: Inglés (Estados Unidos)

Con formato: Inglés (Estados Unidos)

Con formato: Inglés (Estados Unidos)

Con formato: Inglés (Estados Unidos) 
${ }^{61}$ Butterfield, op.cit. (ref.19), p. 190. 